\title{
Huhungan Acute Kidney Injury dan Skor Pelod pada Pasien Penyakit Kritis
}

\author{
Risa Vera, ${ }^{*}$ Silvia Triratna, ${ }^{*}$ Dahler Babrun, ${ }^{*}$ Theodorus ** \\ *Departemen Ilmu Kesehatan Anak Fakultas Kedokteran Universitas Sriwijaya/RS Moh. Hoesin, \\ Palembang. \\ **Program Studi Biomedik Fakultas Kedokteran Universitas Sriwijaya, Palembang.
}

\begin{abstract}
Latar belakang. Insiden dan mortalitas acute kidney injury (AKI) pada pasien penyakit kritis cukup tinggi, diperlukan penilaian secara objektif menggunakan skor prognostik dalam menentukan prognosis pasien yang disertai AKI.

Tujuan. Mengetahui hubungan antara AKI dan skor PELOD pada pasien penyakit kritis.

Metode. Penelitian dilakukan di UPIA RS Moh. Hoesin Palembang selama bulan November 2011-Maret 2012, sampel dipilih secara konsekutif. Hubungan antara AKI dan skor PELOD dianalisis dengan uji Kai Kuadrat, Fisher, dan Mann-Whitney. Kesintasan dianalisis dengan uji Kaplan Meier.

Hasil. Subjek penelitian terdiri dari 113 anak, prevalensi AKI sebesar 60,2\%, AKI risk 41,2\%, injury 25\%, dan failure 33,8\%. Prevalensi kematian pasien AKI 57,4\%, risk 39,3\%, injury 47,1\%, failure 87\%. Skor PELOD lebih tinggi pada pasien AKI $(19,7 \pm 1,62$ vs $6,8 \pm 1,31)$. Analisis korelasi dan regresi antara kadar kreatinin serum dan skor PELOD didapatkan $r=0,518$ dan $r^{2}=0,256$.

Kesimpulan. Acute kidney injury dan skor PELOD memiliki hubungan positif, dan kontribusi AKI terhadap variasi skor PELOD 25,6\% menjelaskan bahwa pasien penyakit kritis dengan skor PELOD rendah akan tetap memiliki prognosis yang buruk jika pasien tersebut mengalami AKI.
\end{abstract}

Sari Pediatri 2013;15(3):181-5.

Kata kunci: acute kidney injury, skor PELOD, penyakit kritis

$A$ cute kidney injury (AKI) atau gangguan ginjal akut (GgGA) merupakan suatu keadaan kemampuan ginjal yang berkurang untuk mempertahankan keseimbangan cairan

\footnotetext{
Alamat korespondensi:

Dr. Risa Vera, SpA. RS Medika Stannia Bangka. Jl. Jend. Sudirman No. 3, Sungai Liat, Bangka, Bangka-Belitung. Email.risa_vera@idai.or.id, risa_vera@yahoo.co.id
}

dan elektrolit, mempertahankan produksi urin yang adekuat, dan mengeluarkan zat-zat toksik dari dalam tubuh. Gangguan ini bersifat akut dan reversible jika penyebabnya segera diatasi. ${ }^{1-4}$

Penelitian tentang AKI pada anak yang dirawat di unit pelayanan intensif anak (UPIA) menunjukkan hasil yang bervariasi karena pemahaman berbeda pada setiap institusi tentang dasar diagnosis AKI. ${ }^{5-8}$ Angka kematian pasien sakit kritis yang disertai AKI 
cukup tinggi dan dipengaruhi oleh derajat AKI, derajat berat penyakit, dan gangguan fungsi organ yang menyertai penyakit tersebut. Penilaian prognosis pasien yang dirawat di UPIA perlu dilakukan secara objektif dengan menggunakan skor prognostik yang telah baku. ${ }^{9-11}$

\section{Metode}

Penelitian cross-sectional untuk mengetahui prevalensi dan mortalitas AKI di UPIA, Kelompok kasus adalah subjek yang mengalami AKI, sedangkan kelompok kontrol subjek yang tidak mengalami AKI. Analisis kesintasan digunakan untuk memprediksi kesintasan pada pasien AKI.

Subjek penelitian adalah pasien penyakit kritis yang dirawat di UPIA Rumah Sakit Moh Hoesin, Palembang usia $\geq 30$ hari sampai 15 tahun yang diambil secara konsekutif. Orangtua atau wali memberikan persetujuan secara tertulis setelah diberikan penjelasan. Kriteria eksklusi adalah subjek yang sebelumnya telah terdiagnosis penyakit ginjal kronis dan subjek yang tidak dapat dilakukan pemeriksaan darah secara lengkap sesuai dengan protokol.

Penentuan skor PELOD dilakukan saat pasien masuk dalam perawatan di UPIA dan diulang saat subjek penelitian teridentifikasi mengalami AKI berdasarkan peningkatan kadar kreatinin serum dan penurunan LFG, penentuan skor PELOD ulang juga dilakukan jika pasien mengalami perburukan, ataupun perbaikan dari kondisi sebelumnya. Skor PELOD pada pasien AKI adalah skor PELOD saat pasien terdiagnosis AKI, sedangkan skor PELOD pada pasien yang tidak mengalami AKI adalah skor PELOD yang paling rendah selama pasien dirawat di UPIA. Seluruh pasien dipantau selama perawatan untuk mengetahui hasil perawatan yaitu hidup atau mati.

\section{Hasil}

Subjek penelitian yang memenuhi kriteria inklusi 113 orang dengan rentang usia 1-169 bulan (median 36 bulan). Acute kidney injury ditemukan 68 subjek $(60,2 \%)$, etiologi terbanyak adalah AKI prerenal dan derajat terbanyak adalah derajat risk. Risiko kematian AKI renal meningkat 3,24 kali dibandingkan AKI
Tabel 1. Karakteristik subjek penelitian

\begin{tabular}{lcc}
\hline Karakteristik & $\mathrm{n}$ & $\%$ \\
\hline Usia & & \\
1bulan-12 bulan & 44 & 38,9 \\
$>1$ tahun-5 tahun & 35 & 31 \\
$\quad$ > tahun-12 tahun & 24 & 21,2 \\
$\quad$ 12 tahun-15 tahun & 10 & 8,8 \\
Jenis kelamin & & \\
$\quad$ Laki-laki & 50 & 44,2 \\
$\quad$ Perempuan & 63 & 55,8 \\
Status gizi & & \\
Baik & 52 & 46 \\
Kurang & 47 & 41,6 \\
Buruk & 8 & 7,1 \\
Lebih & 6 & 5,3 \\
Ventilasi mekanik & & \\
Dengan & 54 & 47,8 \\
Tanpa & 59 & 52,2 \\
Hasil rawat & & \\
Meninggal & 51 & 45,1 \\
Hidup & 62 & 54,9 \\
Penyakit primer & & \\
Neurologis & 26 & 23 \\
Kardiovaskular & 4 & 3,5 \\
Nefrologi & 1 & 0,9 \\
Respirasi & 30 & 26,5 \\
Infeksi & 38 & 33,6 \\
Endokrin & 1 & 0,9 \\
Gastroenterologi & 4 & 3,5 \\
Luka bakar & 4 & 3,5 \\
Paska operasi & 5 & 4,4 \\
\hline
\end{tabular}

prerenal, semakin tinggi derajat AKI maka persentase kematian semakin meningkat. Berdasarkan uji statistik terdapat perbedaan bermakna jumlah pasien yang meninggal pada kelompok AKI risk dan failure ( $\mathrm{p}=0,001)$, demikian pula pada kelompok injury dan failure ( $\mathrm{p}=0,013)$.

Lama rawat subjek dengan AKI minimal 6 jam dan maksimal 360 jam. Berdasarkan uji Kaplan Meier didapatkan perbedaan bermakna lama rawat pada kelompok AKI dan tidak AKI $(\mathrm{p}=0,014)$ serta pada AKI risk, injury, dan failure $(\mathrm{p}=0,004)$. Terdapat perbedaan bermakna antara skor PELOD kelompok AKI dan tidak AKI $(\mathrm{p}<0,001)$ serta kelompok AKI risk, injury dan failure $(\mathrm{p}<0,001)$. Titik koordinat kurva ROC ditunjukkan sensitivitas $83,8 \%$ dan spesifisitas $73,3 \%$ didapatkan cut off point nilai skor PELOD terhadap AKI 10,5. Pasien dengan 
Tabel 3. Distribusi skor PELOD pada subjek penelitian

\begin{tabular}{lccc}
\hline Skor PELOD & Rerata & SD & $\mathrm{p}$ \\
\hline AKI & 19,97 & 1,62 & $<0,001^{*}$ \\
Risk & 14,32 & 1,99 & $<0,001^{* *}$ \\
Injury & 18,65 & 2,84 & \\
$\quad$ Failure & 27,83 & 2,95 & \\
Tidak AKI & 6,58 & 1,31 & \\
Cut off point & AKI & Tidak AKI & \\
$<10,5$ & $11(25 \%)$ & $33(75 \%)$ & $<0,001^{* * *}$ \\
$\geq 10,5$ & $57(82,6 \%)$ & $12(17,4 \%)$ & OR $14,25(5,67-35,89)$ \\
& Risk & Injury & Failure \\
$<10,5$ & $7(63,6 \%)$ & $3(27,3 \%)$ & $1(9,1 \%)$ \\
$\geq 10,5$ & $21(36,8 \%)$ & $14(24,6 \%)$ & $22(38,6 \%)$ \\
\hline
\end{tabular}

* Uji Mann-Whitney

** Uji Kruskal-Wallis

*** Uji kai kuadrat

Tabel 2. Distribusi AKI pada subjek penelitian

\begin{tabular}{|c|c|c|c|c|c|c|}
\hline \multirow{3}{*}{ AKI } & \multicolumn{4}{|c|}{ Prognosis } & \multirow{3}{*}{ OR (IK95\%) } & \multirow{3}{*}{$\mathrm{p}$} \\
\hline & \multicolumn{2}{|c|}{ Meninggal } & \multicolumn{2}{|c|}{ Hidup } & & \\
\hline & $\mathrm{n}$ & $\%$ & $\mathrm{n}$ & $\%$ & & \\
\hline \multicolumn{7}{|c|}{ AKI (n=113) } \\
\hline $\mathrm{Ya}$ & 39 & 57,4 & 29 & 42,6 & $3,69(1,63-8,37)$ & $0,001 \#$ \\
\hline Tidak & 12 & 26,6 & 33 & 73,3 & & \\
\hline \multicolumn{7}{|c|}{ Etiologi $(\mathrm{n}=68)$} \\
\hline Prerenal & 33 & 54,1 & 28 & 45,9 & $3,24(1,41-7,44)$ & $<0,001 \# \#$ \\
\hline Renal & 6 & 85,7 & 1 & 14,3 & & \\
\hline \multicolumn{7}{|c|}{ Derajat $(n=68)$} \\
\hline Risk & 11 & 39,3 & 17 & 60,7 & $1,373(0,41-4,64)$ & $0,609^{*}$ \\
\hline Injury & 8 & 47,1 & 9 & 52,9 & $10,3(2,46-43,1)$ & $0,001^{* *}$ \\
\hline Failure & 20 & 87 & 3 & 13 & $7,5(1,60-35,1)$ & $0,013^{* * *}$ \\
\hline
\end{tabular}

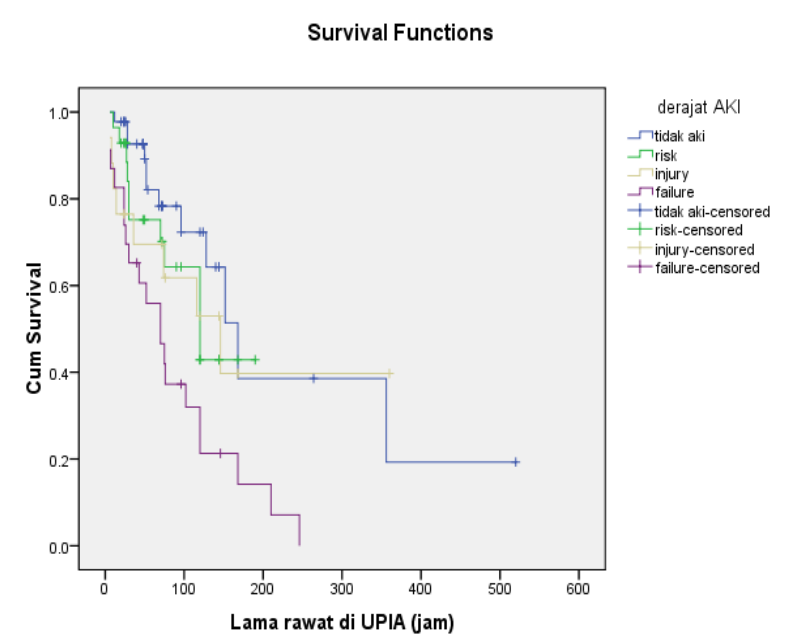

Gambar 1. Kurva Kaplan Meier berdasarkan lama rawat pada pasien AKI skor PELOD $\geq 10,5$ lebih banyak mengalami AKI dibandingkan pasien dengan skor PELOD $<10,5$ (Tabel 3).

Analisis korelasi dan regresi antara kadar kreatinin serum dan skor PELOD diperoleh nilai korelasi $(\mathrm{r})=0,512,\left(\mathrm{r}^{2}\right)=0,262$, dan koefisien regresi $(\mathrm{B})=10,3$. Hal tersebut menunjukkan, walaupun memiliki hubungan positif yang cukup kuat dan bermakna dengan skor PELOD, kadar kreatinin serum hanya dapat menjelaskan variasi skor PELOD 26,2\%, sedangkan sisanya dijelaskan oleh variabel lain. Persamaan regresi yang dapat digunakan untuk memprediksi skor PELOD adalah

\section{Skor PELOD = 5,47 + 10,3 (kreatinin serum)}




\section{Pembahasan}

Prevalensi AKI 60,2\% di UPIA RSMH, AKI derajat risk $41,2 \%$, injury $25 \%$, dan failure 33,8\%. Penelitian Freire $\mathrm{dkk}^{6}$ menemukan prevalensi AKI 30,6\% dengan distribusi risk 39,1\%, injury 39,1\%, dan failure $21,8 \%$. Plotz $\mathrm{dkk}^{7}$ melaporkan insiden yang tidak jauh berbeda dengan hasil penelitian kami, yaitu $58 \%$, tetapi dengan distribusi risk 52\%, injury 37\%, dan failure $11 \%$. Perbedaan prevalensi karena populasi penelitian dan perbedaan karakteristik masing-masing penelitian..$^{5-8}$

Angka kejadian AKI yang tinggi ditegakkan berdasarkan kriteria pRIFLE, ditunjukkan bahwa kriteria ini memiliki sensitivitas yang tinggi terhadap gangguan fungsi ginjal, bahkan pada tahap awal. ${ }^{12}$ Uchino dkk ${ }^{13}$ dan Hoste dan Kellum ${ }^{14}$ melaporkan bahwa kriteria RIFLE dapat mendeteksi AKI 18\% dari seluruh pasien yang dirawat di rumah sakit, dan $67 \%$ dari seluruh pasien penyakit kritis. ${ }^{15}$ Terdapat perbedaan lama rawat kelompok AKI dan tidak AKI, serta perbedaan lama rawat kelompok AKI risk, injury, dan failure. Alkandari $\mathrm{dkk}^{16}$ melaporkan bahwa pasien AKI memiliki angka kematian yang lebih tinggi dan lama rawat yang lebih singkat.

Kematian pasien AKI 57,4\% dengan risiko kematian 3,69 kali dibandingkan dengan pasien yang tidak AKI, semakin tinggi derajat AKI maka persentasi kematian semakin besar. Hoste dan Kellum ${ }^{14}$ melaporkan peningkatan risiko kematian pada pasien AKI 3 kali, Osterman dan Chang ${ }^{17} 4$ kali, sementara Freire dkk 10 kali. $^{6}$ Plotz $\mathrm{dkk}^{7}$ melaporkan peningkatan risiko kematian pada setiap derajat AKI masing-masing sebesar 10 kali. Angka mortalitas AKI yang tinggi pada berbagai penelitian tersebut menunjukkan bahwa AKI dapat digunakan sebagai indikator prognosis yang buruk pada pasien penyakit kritis. ${ }^{18-20}$

Skor PELOD pasien AKI lebih tinggi dibandingkan pasien yang tidak mengalami AKI, dan skor PELOD juga lebih tinggi pada AKI dengan derajat yang lebih berat. Telah diketahui sebelumnya bahwa baik AKI maupun skor PELOD berperan dalam menentukan prognosis pasien penyakit kritis yang dirawat di UPIA.

Hubungan antara skor PELOD dan AKI diketahui dengan analisis korelasi dan regresi yang bertujuan untuk menilai peran AKI dalam menentukan prognosis pasien. Parameter AKI yang digunakan adalah kadar kreatinin serum karena dianggap mampu mencerminkan gangguan fungsi ginjal secara akurat, selain itu kadar kreatinin serum juga digunakan sebagai parameter disfungsi organ ginjal pada komponen skor PELOD. Hasil analisis menunjukkan bahwa AKI memiliki korelasi positif dengan skor PELOD, tetapi AKI hanya dapat menjelaskan variasi skor PELOD sebesar 26,2\%. Berdasarkan hasil tersebut dapat disimpulkan bahwa AKI menyebabkan prognosis yang buruk, walaupun pada pasien dengan prediksi kematian yang rendah.

Penelitian kami memiliki keterbatasan, yaitu beberapa pemeriksaan laboratorium seperti analisis gas darah dan PT/INR belum tersedia 24 jam sehingga penghitungan skor PELOD tidak dapat dilakukan sesuai waktu yang diinginkan.

\section{Kesimpulan}

Acute kidney injury memiliki hubungan positif dengan skor PELOD, tetapi kontribusi AKI terhadap skor PELOD hanya 26,2\%. Hal tersebut menjelaskan bahwa pasien penyakit kritis dengan skor PELOD rendah akan tetap memiliki prognosis yang buruk jika pasien tersebut mengalami AKI.

\section{Daftar pustaka}

1. Andreoli S. Acute kidney injury in children. Pediatr Nephrol 2009;24:255-63.

2. Osterman M, Chang R. Acute kidney injury in the intensive care unit according RIFLE. Crit Care Med 2007;35:1837-43.

3. Noer M, Soemiyarso N, Prasetyo R. Acute kidney injury. Naskah Lengkap Sinas dan Workshop Nefrologi. IDAI, Bali; 2009.

4. Akcan-Arikan A, Zappitelli M, Lotfis L, Washburn K, Goldstein L. Modified RIFLE criteria in critically ill children with acute kidney injury. Kidney Int 2007; 7:1028-35.

5. Hui-Stickle S, Brewer E, Goldstein S. Pediatric ARF epidemiology at a tertiary care center from 1999 to 2001 . Am J Kidney Dis 2005;45:96-101.

6. Freire K, Bresolin N, Fatah A, Carvalho F, Goes J. Acute kidney injury in children: Incidence and prognostic factors in critically ill patient. Rev Brassilian Intensiva 2010;22:166-74.

7. Plotz F, Hulst H, Twisk J. Effect of acute renal failure 
on outcome in children with severe septic shock. Pediatr Nephrol 2005;20:1177-81.

8. Bhimma R. Newer insight into acute renal failure in children. Pediatric Oncall 2009. (diunduh Oktober 2010) Didapat dari: http://www.pediatriconcall.com/fordoctor/ diseaseandcondition/pediatric nephrology/ acute_renal_failure. asp.

9. Bresolin N, Manthous C, Eggers P. Prognosis for children with acute kidney injury in the intensive care unit. Pediatr Nephrol 2009;24:537-44.

10. Leteurtre S, Martinot A, Duhamel A. Validation of the paediatric logistic organ dysfunction (PELOD) Score: Prospective, Observational, Multicentre. Lancet 2003; 3:192-6.

11. Khwannimit B. A comparison of three organ dysfunction scores: MODS, SOFA, LOD for predicting ICU mortality in critically ill patients. J Med Assoc Thai 2007;90:1074-81.

12. Chang C, Lin C, Jeng C, Chang M, Chen Y. Acute kidney injury classification: comparison of AKIN and RIFLE criteria. Shock 2010;3:247-52.

13. Uchino S, Kellum J, Bellomo R. Acute renal failure in critically ill patients: a multinational, multicenter study. JAMA 2005;7:813-8.
14. Hoste E, Kellum J. Acute kidney injury in sepsis. Nephrol Dial Transplan 2010;25:1738-9.

15. Chim S. Acute renal failure: Medical (non-dialytic) management. Practical Pediatric Nephrology. Hongkong: Medcom Limited; 2005.

16. Alkandari O, Eddington K, Hyder A, Gauvin F, Ducruet T. Acute kidney injury is independent risk factor for pediatric intensive care unit mortality, longer length of stay and prolonged mechanical ventilation in critically ill children: A two-center retrospective cohort study. Crit Care 2011;15:1-12.

17. Osterman M, Chang R. Acute kidney injury in the intensive care unit according RIFLE. Crit Care Med 2007;35:1837-43.

18. Bailey D, Phan V, Litalien C, Ducruet T, Mérouani A, Lacroix $\mathrm{J}$, dkk. Risk factors of acute renal failure in critically ill children: a prospective descriptive epidemiological study. Pediatr Crit Care Med 2007;8:29-35.

19. Barrantes F, Tian J, Vazquez R, Amoateng-Adjepong $\mathrm{Y}$, Manthous C.Acute kidney injury criteria predict outcome of critically ill patients. Crit Care Med 2008;36:1397-403.

20. Cerda J, Lamiere N, Eggers P. Epidemiology of acute kidney injury. Clin J Am Soc Nephrol 2008;3:881-6. 